\title{
Educating Reason: Critical Thinking, Informal Logic, and the Philosophy of Education
}

\author{
Part Two: Philosophical Questions \\ Underlying Education for Critical Thinking [1]
}

\author{
HARVEY SIEGEL University of Miami
}

\section{Editors' Note}

Part One of Professor Siegel's long essay, "Educating Reason: Critical Thinking, Informal Logic and the Philosophy of Education,"' was published not in this journal but in the American Philosophical Association's Newsletter on Teaching Philosophy. In the article printed below, which can be read independently of Part One, Siegel addresses the question of the justification of critical thinking as an educational ideal. In our view the issues involved are sufficiently important, and Siegel's handling of them sufficiently perspicacious, to justify the publication of Part Two by itself.

\section{Introduction}

In Part One of this essay I presented a critique of the analysis of critical thinking offered by John McPeck; offered an alternative conception of critical thinking; and argued that taking the educational program of the "informal logic/critical thinking movement" (ILM) seriously - that is, taking seriously the idea that we should strive, in our educational institutions and practices, to help students to become critical thinkers-requires confronting fundamental philosophical questions concerning the justification of educational aims and ideals. In what follows I present a putative justification for taking critical thinking to be a fundamental educational ideal. (I also discuss, much more briefly, epistemo- logical questions which are raised by a commitment to critical thinking.) It is my hope that, even if the putative justification offered proves to be unsatisfactory, other friends of critical thinking will recognize and take seriously the justificatory task.

\section{Why Does Critical Thinking Need To be Justified?}

I briefly addressed this question in my earlier paper, but more needs to be said.

It is not the case that critical thinking is universally accepted as an educational ideal. (Even if it were, a justification would still be called for, on my view.[2]) For example, various defenders of "scientific" creationism/opponents of evolution deny that science education should strive to expose students to scientifically legitimate alternative theories, and to help students to become capable of objectively evaluating evidence for, and of fairly assessing the relative merits of, the alternatives. While some only implicitly deny this, and pay lip service to critical evaluation, others explicitly suggest that science education ought to conform, not to the ideal of critical thinking, but rather to basic religious tenets.[3] More generally, fundamentalists of various stripes, and "T.V. preachers" such as Jerry Falwell, argue that parents own their children and have an unbridled right to indoctrinate their children into beliefs of all sorts.[4] More genrally still, members of the general public (not to mention 
members of school boards and school administrations!) often argue against the exposure of students to "dangerous" ideas, e.g., to "revisionist" ideas in U.S. and world history and political science courses, to (non-distorted) communist/socialist/Marxist ideas in economics courses, to "liberal" (or "conservative") ideas regarding sex and related matters in health and hygiene courses, etc. As a strictly political matter, those who have opinions about, and determine the direction of, the education of children and young adults are not universally agreed that critical thinking should be regarded as a fundamental educational ideal.

But the challenge to critical thinking is mounted not only at the level of the "common person" who may or may not be active in the guidance of the education of young persons. The ideal is also challenged by several factions of the academic-intellectual community. For example, many feminists scholars distinguish between "male" and "female" thinking, label "rational" thinking (which I argued in Part One is coextensive with critical thinking) as "male", and decry it as incomplete, biased, sexist, or worse. The educational vision promulgated by such theorists is not one which is compatible with the ideal of critical thinking. [5] Similarly, in literary theory deconstructionists such as Derrida deride rationality as "logocentric." [6] And, as I argue below, some Marxists and other ideologues reject critical thinking as biased and bound up with unacceptable hegemonistic interests; and a distressing number of contemporary epistemologists and philosophers of science favor one or another version of epistemological relativism, which also undercuts the educational ideal of critical thinking. So within the scholarly community, no less than in the wider community, there are those who reject the idea that our educational institutions and activities ought to be organized and carried out with a view to fostering in students the skills, abilities and dispositions which constitute cri- tical thinking.

We could, of course, just ignor these foes of critical thinking, secure i the knowledge that we right-minde thinkers recognize a fundamental edu cational ideal when we see one. Bu this approach will not do, if we regarc ourselves as critical thinkers who hono the demand for reasons and justifica. tion of our convictions. To justify critical thinking as an educational ideal is to offer a positive account of the desirability and worthiness of educational efforts which have as their aim the fostering of critical thinking in students; it is also to show that the sorts of criticisms of the ideal mentioned above can be defeated, that the ideal can survive the criticisms. This is a large task. I do not claim to have completed it in what follows. But I do hope that it is a start.

\section{The Justification of Critical Thinking As An Educational Ideal [7]}

A preliminary point: If we accept critical thinking as an educational ideal, we explicitly acknowledge the desirability of the attainment by students of self-sufficiency and autonomy. If we think it good that a student become a critical thinker, we must approve as well of the student's ability and disposition to consult her own independent judgment concerning matters of concern to her. The critical thinker must be autonomous - that is, free to act and judge independently of external constraint, on the basis of her own reasoned appraisal of the matter at hand. Relatedly, if we take the ideal of critical thinking seriously, we must endeavor to render the student self-sufficient and capable of determining (insofar as is possible) her own future. In this way we aim to bring the student quickly to the point at which she can join the adult community and be recognized as a fellow member of a community of equals. Critical thinking, in its open striving for the student's early achievement of autonomy and self-sufficiency, is incompatible with any educational 
plan which aims at the preparation of the student for some preconceived adult role or pre-established slot in some social arrangement. Rather, critical thinking aims at getting the student to be an active participant in the establishment of her own adult life, and of the social arrangements in which she is engaged.

How can the educational ideal of critical thinking, which promulgates the development in students of skills of reason assessment, the critical spirit, and autonomy and self-sufficiency, be justified? A full answer would far exceed the space available here. But I would like briefly to offer three considerations which serve to justify critical thinking as an educational ideal.

First, we are morally obligated to treat students (and everyone else) with respect. The Kantian principle of respect for persons requires that we treat students in a certain mannerone which honors students' demand for reasons and explanations, deals with students honestly, and recognizes the need to confront students' independent judgment. For what does it mean for a teacher to recognize the equal moral worth of students and to treat students with respect? Among other things, it means recognizing the student's right to question, to challenge, and to demand reasons and justifications for what is being taught. The teacher who fails to recognize these rights of the student fails to treat the student with respect, for treating the student with respect involves recognizing the student's right to exercise his or her independent judgment and powers of evaluation. To deny the student this right is to deny the student the status of "person of equal worth." To treat students with respect is, moreover, to be honest with them. To deceive, indoctrinate, or otherwise fool students into believing anything, even if it is true, is to fail to treat them with respect.

The general moral requirement to treat persons with respect thus applies to the teacher's dealing with his or her students simply because those students are persons and so are deserving of respect. It is independent of any specific educational aim. However, it offers justification for taking critical thinking to be a legitimate educational ideal in that the way one teaches, according to what might be called the critical manner, is in crucial respects isomorphic to the way one teaches so as to respect students. In both, the student's right to question, challenge, and seek reasons and justifications must be respected. In both, the teacher must deal honestly with the student. In both, the teacher must submit reasons for taking some claim to be true to the student's independent judgment and critical scrutiny. In most respects, then, teaching in the critical manner simply is to teach in such a way as to treat students with respect; the obligation to treat students with the respect they are due as persons thus constitutes a reason for adopting the critical manner. In short, this manner of teaching is morally required; it is also part and parcel of the ideal of critical thinking. So morality provides one powerful reason for operating our educational institutions in a way which accords with that ideal. [8]

The second reason for taking critical thinking to be a worthwhile educational ideal has to do with education's generally recognized task of preparing students to become competent with respect to those abilities necessary for the successful management of one's adult life. We educate, at least in part, in order to prepare children for adulthood, but we cannot say in advance that Johnny will be a pilot, for example, and arrange his education accordingly, for Johnny might well decide to be something else. In general, when we say that education prepares children for adulthood, we do not mean for some specific adult role. Rather, we mean that education prepares children generally for adulthood. One such general aspect of adulthood is the power and ability to control one's own life. We guide a child's education primarily because a child cannot responsibly guide it, but we seek to bring the child, 
as quickly as possible, to the point where the child can "take over the reins" and guide his or her own education and life generally. That is, we seek to make the child self-sufficient; to empower the student to control his or her destiny. [9] To get the student to the point where he or she can competently control his or her life is to bring the student into the adult community, to recognize the student as a fellow member of a community of equals. To thus empower the student is to raise that person, in the most appropriate sense of the term, to his or her "fullest potential." Indeed, this is a fundamental obligation to children. Without proper training, children would not get to the point where they could competently control their own destinies; many options would be forever closed to them because of their poor training. To meet our obligation to children to prepare them well for adulthood, we must try to educate them in such a way that they are maximally self-sufficient.

How can we organize educational activities so as to empower the student? My suggestion, predictably enough, is that we organize those activities according to the dictates of critical thinking. To help students to become critical thinkers is to "encourage them to ask questions, to look for evidence, to seek and scrutinize alternatives, to be critical of their own ideas as well as those of others." [10] Such encouragement is likely to lead to the student's self-sufficiency, for as Scheffler writes:

This educational course precludes taking schooling as an instrument for shaping [students'] minds to a preconceived idea.

For if they seek reasons, it is their evaluation of such reasons that will determine what ideas they eventually accept.[11]

By encouraging critical thinking, then, we teach the student what we think is right, but we encourage the student to scrutinize the evidence and judge independently the rightness of our claims. In this way the student becomes a competent judge; more importantly, the student becomes and independent judge. That is, the student makes her own judgments regarding the appropriateness of alternative beliefs, courses of action, and attitudes. Such independence of judgment is the sine qua non of self-sufficiency. The selfsufficient person is, moreover, a liberated person; such a person is free from the unwarranted control of unjustified beliefs, unsupportable attitudes, and paucity of abilities which can prevent that person from competently taking charge of his or her own life. Critical thinking thus liberates[12] as it renders students self-sufficient. Insofar as we recognize our obligation to prepare children to become competent, selfsufficient adults, that obligation provides a justification for the ideal of critical thinking, for education as conceived along the lines suggested by that ideal recognizes that obligation explicitly. Here, then, is a second reason for taking critical thinking to be a legitimate educational ideal.

Finally, I come to the third reason for taking critical thinking to be an educational ideal. As I argued in Part One, critical thinking is best seen as coextensive with rationality, and rationality is concerned with reasons. For a person to be rational, that person must (at least) grasp the relevance of various reasons for judgments and evaluate the weight of such reasons properly. How does a person know how to evaluate reasons properly?

A plausible account of the proper evaluation of reasons suggests that a person learns the proper assessment of reasons by being initiated into the traditions in which reasons play a role. Education, on this view, amounts to the initiation of the student into the central human traditions.[13] These traditions-science, literature, history, the arts, mathematics, and so onhave evolved, over the long history of their development, guidelines concerning the role and nature of reasons in their respective domains. Thus, for example, a prospective scientist must learn, among other things, what counts as a good reason for or against some 
hypothesis, theory, or procedure; how much weight the reason has; and how it compares with other relevant reasons. Science education amounts to initiating the student into the scientific tradition, which in part consists in appreciating that tradition's standards governing the appraisal of reasons. [14]

Such appraisal is, moreover, not static. Standards of rationality evolve and must be seen as part of a constantly evolving tradition:

Rationality in natural inquiry is embodied in the relatively young tradition of science, which defines and redefines those principles by means of which evidence is to be interpreted and meshed with theory. Rational judgment in the realm of science is, consequently, judgment that accords with such principles, as crystallized at the time in question. To teach rationality in science is to interiorize these principles in the student, and furthermore, to introduce him to the live and evolving tradition of natural science....

Similar remarks might be made also with respect to other areas, e.g. [history], law, philosophy and the politics of democratic society. The fundamental point is that rationality cannot be taken simply as an abstract and general idea. It is embodied in multiple evolving traditions, in which the basic condition holds that issues are resolved by reference to reasons, themselves defined by principles purporting to be impartial and universal.[15]

If we can conclude that education is largely a matter of initiating students into the rational traditions, and if we can agree that such initiation consists in part in getting the student to appreciate the standards of rationality which govern the assessment of reasons (and so proper judgment) in each tradition, then we have a third reason for taking critical thinking to be an educational ideal. Critical thinking, we have seen, recognizes the importance of getting students to understand and appreciate the role of reasons in rational endeavor, and of developing in students those traits, attitudes, and dispositions which encourage the seeking of reasons for grounding judgment. Understanding the role and criteria of evaluation of reasons in the several rational traditions is crucial to being successfully initiated into those traditions. If education is seen as initiation into the rational traditions, then we have a reason for taking critical thinking to be an educational ideal: critical thinking is a legitimate educational ideal because it seeks to foster in students those traits, dispositions, and attitudes which are conducive to the successful initiation of students into the rational traditions. Seeing education as initiation thus offers justification for the ideal of critical thinking

\section{Two Potential Objections}

These three putative justifications for taking critical thinking as an educational ideal are clearly in need of further development. They do offer, however, at least the beginnings of a justification for educational efforts aimed at fostering critical thinking. There are other considerations, unfortunately, which tend to cast doubt on the justifiability of critical thinking as an educational ideal, and a full justification must deal adequately with these other considerations. I cannot do so here; but I would be remiss if I did not at least mention them as problems a full-scale effort to justify critical thinking must face.

First, there is the problem of ideology. Many educational and social theorists argue that educational aims are thoroughly ideological and must necessarily be so. According to such thinkers, the educational aims one adopts are determined entirely by the ideology one is committed to. Thus the adoption of critical thinking is not something that can be rationally justified; rather, it simply reflects the (liberal, Western, capitalist, hegemonist, atheistic, imperialistic, etc.) prior ideological commitment of the person or group doing the adopting. Since that prior ideological commitment is fundamental, or basic, or "pre-ra- 
tional," it does not itself admit of rational justification. Consequently, no educational ideal can be rationally justified, critical thinking or any other. So the effort of justifying critical thinking must, necessarily, fail.

The problem of ideology just sketched is a significant one. It is simplistically drawn here, but it can be presented in a powerful way. [16] It is one that must be faced by those who would seek to justify our efforts at fostering the development of critical thinking. I myself think it can be defeated. In another place[17] I argue that rationality cannot itself be conceived as a notion which is relative to ideology, but rather that it must be seen as prior to, and transcendent of, ideology. I argue that the problem of ideology cannot even be articulated coherently unless rationality is conceived as ideology-neutral or -transcendent, for the coherent articulation of the problem presupposes standards of rationality. I argue, in addition, that the thesis that ideological commitment is prior to rationality, or prerational, and so cannot be justified, is false; that the rational evaluation of ideology is possible; and consequently that commitments to educational aims, even if ideologically determined, can be rationally justified. Thus it is my view that the justification of critical thinking as an educational aim can survive the problem of ideology. But it is a problem which defenders of critical thinking must address.

A second problem to be faced by the defender of the educational ideal of critical thinking is that of relativism. That ideal espouses the virtue of attention to, and respect for, reasons. But according to a popular philosophical view, thinking in general, and the assessment of reasons in particular, is always, necessarily, bound by some conceptual framework; there exist alternative, incompatible frameworks; and therefore critical thinking must be understood as being framework-bound. For Kuhn, the objection is put in terms of paradigms; for Wittgenstein, in terms of "forms of life," [18] In either case, the upshot is a radically relativized conception of critical thinking, in which the notion of "good reason" is relativized to some framework, so that a good reason for believing or acting is a good reason only for those who utilize some particular framework. Since on this view there is no nonneutral way to choose from among various alternative frameworks, the very notion of "good reason" is rendered empty, except within some particular framework; the ideal of critical thinking emasculated insofar. Such a view, if correct, undermines critical thinking to the extent that it constitutes a general educational ideal, since there could be no general account of the constitution of good reasons which could be applicable across frameworks. Indeed, taking relativism seriously requires relinquishing the very notion of a general education ideal, since such ideals would themselves need to be relativized to particular frameworks. In these two ways, then, relativism poses a challenge to the educational ideal of critical thinking.

The problem of relativism is raised not just by work in epistemology, philosophy of science, and philosophy of language; it is raised as well by work which explicitly concerns critical thinking and informal logic. Here I have in mind Richard Paul's emphasis on the notion of world view, and his seeming suggestion that criteria of evaluation of informal arguments and of reason assessment are ultimately grounded in world views.[19] Such a position, however, raises the relativism problem in acute form. For the question immediately arises as to whether world-views themselves admit of evaluation in a non-question-begging way. Are there criteria of reason assessment which transcend world-views? If so, then criteria of reason assessment cannot be grounded in world-views. If not, then doesn't reason assessment ultimately collapse, since alternative views will each be grounded in alternative, incompatible, and uncriticizable world views?

As with the problem of ideology, I 
believe that the problem of relativism can ultimately be handled by the theory of critical thinking. The rival frameworks conception of criteria assessment can be challenged, as can relativism directly. [20] In particular, I think a case can be made that, in the relevant sense, criteria of reason assessment can transcend world views and can be neutral, objective, and non-questionbegging. But the case must be made, and the notion of world view and its use by critical thinking theorists such as Paul clarified accordingly. At the very least, defenders of the educational ideal of critical thinking need to address this fundamental philosophical problem.

I have been arguing that the problems of ideology and relativism can adequately be dealt with. More generally, I have been arguing that critical thinking can be justified as an educational ideal. More generally still, I have been arguing that these problems and justifications are among a series of fundamental philosophical tasks that those who embrace the ideal of critical thinking must explicitly confront. The tasks considered thusfar fall squarely within the philosophy of education, since they stem from the effort to justify critical thinking as an educational ideal. Therefore, I am arguing that proponents of critical thinking and/or informal logic as educational desiderata must do some philosophy of education. (Paul's suggestion that ILM place on its agenda the "analysis of the ultimate ends of education" [21] is thus entirely in keeping with my point here, and is most welcome, as is McPeck's explicit consideration (discussed in Part One) of the connection between critical thinking and education.) In the next section I argue that ILM must do some epistemology as well.

In closing this section, I would like to make one final observation. If critical thinking is conceived as an educational ideal, then the important question is not "Is there a generalized skill of critical thinking?", but rather, "How does critical thinking manifest itself?"
The answer to the latter question is: "In both subject-specific and in general ways, for reasons can be both subjectspecific and general." The debate between McPeck, Ennis and others over the first question mentioned is thus in an important sense beside the point.[22]

\section{Critical Thinking and Epistemology}

The fundamental epistemological task facing proponents of critical thinking/informal logic is that of formulating a theory of rationality and of the epistemic force of reasons. Since, as 1 argued in Part One, a critical thinker is one who is appropriately moved by reasons, i.e. one who recognizes the cognitive force of reasons and who seeks to believe and act in accordance with reasons, a full conception of critical thinking must include an epistemological account of reasons. Such an account must involve a consideration of criteria which distinguish good from bad reasons [23]; it must also distinguish genuine from spurious warrant and identify the epistemological source of the warrant or justification that reasons provide for beliefs and actions. The theory of critical thinking is, on this view, primarily an epistemological activity, and those engaged in developing the theory of critical thinking must pay attention to the epistemological dimensions of critical thinking. The theorist of critical thinking must, in short, do some epistemology.[24]

McPeck suggests a similar view. He too argues that epistemology is central to critical thinking. [25] But McPeck's discussion of the relation between critical thinking and epistemology is problematic. For McPeck, the "epistemological approach" involves striving for an understanding of the constitution of good reasons for beliefs, so that

A student would learn not only what is thought to be the case in a given field (that is, the 'facts') but also why it is so regarded. With this kind of understanding.... a person is then in a position 
to make the kinds of judgement required of a critical thinker.(157)

On this view, the student is a critical thinker in some content area, e.g. science, if the student understands the criteria of evaluation and justification of scientific beliefs. To have this understanding is to have an understanding of the epistemology of science. McPeck is quite explicit that good reasons, and so epistemology, are subject-specific - not just reasons, but criteria for assessing the goodness of reasons are subject-specific. Epistemology is to be replaced by a series of epistemologies, one for each "field of human endeavor":

In chapter 2 it was argued that epistemology is, in effect, the analysis of good reasons for belief, including their specific character and foundation. Also, because collective human experience has discovered that different kinds of beliefs often have different kinds of good reason supporting them, it follows that there will be many different epistemologies corresponding to different fields of human endeavor. A corollary of this is that logic itself is parasitic upon epistemology, since logic is merely the formalization of good reasons once they have been discovered. Thus epistemology, and to some extent logic, have intra-field validity but not necessarily inter-field validity.... (Most programmes for critical thinking effectively deny this proposition, hence my disagreement with them.) (155)

There is a confusion here in McPeck's use of "epistemology." Epistemology is the general study of reasons, warrant, and justification, and a student striving to be a critical thinker in science does not study "the epistemology of science," understood to be distinct from "the epistemology" of other subject areas. Rather, that student strives to understand the specific principles and criteria by which scientific reasons are assessed, supplemented by a deeper understanding of the nature of reasons, warrant and justification generally. McPeck uses "epistemology" to refer both to subject-specific criteria of reason assess- ment, and to the general account of what it is to be a reason, to offer warrant for a belief, and to be justified. Once this confusion is noted, McPeck's claim that epistemology has "intrafield" validity but not necessarily inter-field validity" collapses.[26] McPeck is surely right that students should come to learn why reasons for given claims in particular fields are regarded as strong, powerful, compelling, weak, trivial, and so on according to the criteria for assessing reasons in those fields. But such an "epistemology of the subject" is only a part of epistemology as usually understood. For the student who is to be a critical thinker must come to understand not only the criteria of reason assessment in specific fields, but also the nature of reasons generally and the fact that good reasons in different fields, singled out as good by different field-relative criteria, nevertheless stand in the same relation to the beliefs they support despite their being singled out by disparate criteria. If not the student will have only the most shallow understanding of "the epistemology of the subject" - "here we regard this sort of thing as a good reason" - without understanding why this sort of thing should count as a reason here, but another sort of thing as a reason there. In short, McPeck's call for an epistemological approach to critical thinking stops short of a fully epistemological approach, for it fails to recognize that epistemology conceived as inquiry into the nature of reasons, warrant, and justification speaks to, and backs, the particular criteria of reason assessment McPeck refers to as "the epistemology of the subject."

It is perhaps worth noting that McPeck's own discussion belies his construal of epistemology as fieldor subject-specific. For consider McPeck's claim that epistemology has intra-field but not necessarily interfield validity, and the reasons he offers in support of that claim. Are those reasons, or the criteria which sanction them, field-specific? If so, to what field? To raise these questions is to 
realize that epistemology, understood as McPeck does as the analysis of good reasons, cannot be conceived of as subject- or field-specific. For (a) many reasons and beliefs are not subjectspecific, and so fall under no specific set of reason-assessment criteria; and more importantly, (b) critical thinking requires not simply a grasp of fieldspecific criteria of reason assessment, but also a general understanding of the nature of reasons, warrant and justification as these notions function across fields. [27, 28]

If critical thinkers require such general understanding, then theorists of critical thinking must strive to develop such a general account of the nature of reasons, warrant and justification. They must, in particular, develop an analysis of the relation "is a reason for," or, alternatively, an account of what it is for some claim or consideration to be a reason for some other claim, belief, or action. I cannot offer such an account here, although as a first step one might begin[29] by explicating reasons in terms of epistemic worthiness:

\section{$A$ is a reason for $\mathbf{B}=\mathrm{df} \quad \mathbf{A}$ enhances the epistemic worthiness of $B$}

where epistemic worthiness is in turn explicated in terms of truth, probable truth, justification, or worthiness or belief:

A enhances the epistemic worthiness of $\mathbf{B}$ if:

(1) A renders $\mathbf{B}$ more likely to be true, or

(2) A renders $\mathbf{B}$ more justified, or

(3) A renders $\mathbf{B}$ more worthy of belief.

This is the most meager of beginners of an analysis of the relation that $\mathbf{A}$ bears to $\mathbf{B}$ when $\mathbf{A}$ is a reason for $\mathbf{B}$. But such an analysis is crucial to the theory of critical thinking if critical thinking is to be understood in terms of reasons and reason assessment. And it is clear that such an analysis of the nature of reasons and the warrant reasons offer will involve central epistemo- logical investigations. Hence the theorist of critical thinking must perforce engage in epistemology.

It is clear that reasons can be both general and subject-specific. Likewise, it is clear that both formal and informal logic are relevant to the understanding and assessment of reasons. Consequently (and here we see from another angle a point made earlier) the EnnisMcPeck dispute between the generality vs. the field-specific nature of principles of critical thinking[30] is a dispute concerning a bogus issue, as is the more general dispute concerning the realtive merits of formal vs. informal logic for critical thinking. Reasons are the key to critical thinking, and both formal and informal logic are pertinent to the study of reasons, as are both general and field-specific considerations.

A final point regarding the epistemology of critical thinking is that it should not be confused with the pedagogy of critical thinking. For example, I have suggested that the Ennis-McPeck dispute over the general vs. the fieldspecific nature of principles of critical thinking is misconceived insofar as it is conceived as a dispute concerning the epistemology of critical thinking. But it is clearly relevant to pedagogy: should we, in our efforts to help students become critical thinkers, focus on general or subject-specific criteria of reason assessment? If both, to what extent each be emphasized? How do various critical thinking skills transfer? How do we test for student mastery of such skills? These questions, which many in ILM are concerned with, are crucial to the practical education endeavor of imparting critical thinking skills to students. Educational psychology and the psychology of testing are relevant here. Psychology is also relevant to the motivational pedagogical concern: how do we get students to want to be critical thinkers? How, that is, do we impart what I called in Part One the critical spirit or critical attitude?

These questions are of fundamental pedagogical and practical significance, 
and philosophers and others in ILM are to be applauded for attempting to come to grips with them. They should not be confused, however, with questions concerning the epistemology of critical thinking. Theorists of critical thinking would do well to distinguish between the epistemology and the pedagogy of critical thinking.[31]

\section{Conclusions}

Regarding philosophy: I have argued (in Part One) that the critical thinker is best conceived as one who is appropriately moved by reasons, and that this AMR conception of critical thinking consists of both reason assessment skills and the dispositions and habits of mind constitutive of the critical attitude or spirit. I have also suggested that the agenda of ILM must be much more broadly conceived. In particular, that agenda should embrace central questions of epistemology and the philosophy of education. [32] If my own positive views on the several philosophical issues raised prove to be unsuccessful, I hope at least to have performed the useful functions of raising those issues for members of ILM, and demonstrating their centrality for the theory of critical thinking.

Regarding education: If critical thinking is best thought of, as I have suggested, as a fundamental educational ideal, then much more than a single course in "remedial thinking' [33] is needed. The practical, educational task facing proponents of critical thinking is nothing less than that of infusing in students both the abilities requisite for reason assessment and the dispositions and habits of mind constitutive of the critical spirit; of inculcating a grasp of, and respect for, reasons. [34] Critical thinking is not just a good or useful addition to the curriculum. It is, on the contrary, absolutely fundamental to our educational endeavors. [35]

\section{Notes}

[1] Part One, "A Critique of McPeck and a Sketch of an Alternative View," appeared in the American Philosophical Association's Newsletter on Teaching Philosophy, special issue on critical thinking, 1985, pp. 10-13. A version of Part Two was presented at the AILACT session of the Eastern Division A.P.A. Meeting, New York, December 1984. An earlier version of the whole was presented at the Sonoma State University conference on critical thinking, July 1984. I am grateful to Robin Barrow, Ralph Johnson, Stephen Norris, Bruce Suttle, the participants at the two presentations mentioned above, and especially to J. Anthony Blair and John McPeck, for incisive critiques of earlier versions. This work has been partly supported by a grant from Michigan Technological University, for which I am also most grateful.

[2] Though I realize that some philosophers would disagree, claiming rather that a justification is called for only when the view to be justified is challenged, or a demand for a justification issued. I am grateful to J. Anthony Blair for reminding me of this.

[3] Cf. my "The Response to Creationism," Educational Studies 15, Winter 1984, pp. 349-364.

[4] Ibid.

[5] For a critique of one such scholar, cf. my "Genderized Cognitive Perspectives and the Redefinition of Philosophy of Education," Teachers College Record 85, 1983, pp. 100-119.

[6] Cf. egs, Jonathan Culler, On Deconstruction: Theory and Criticism After Structuralism (Ithaca, NY: Cornell Univ. Press); or John Searle's devastating "The World Turned Upside Down," New York 
Review of Books, October 27, 1983, pp. 74-79.

[7] What follows is taken largely from my "Critical Thinking as an Educational Ideal," Educational Forum 45, 1980, pp. 7-23, and my "Educational Ideals and Educational Practices: The Case of Minimum Competency Testing," Issues in Education 1, 1983, pp. 154-170. The justification here offered is expanded upon in Chapter 3 of my Educating Reason: An Essay on Rationality, Critical Thinking, and Education (Routledge \& Kegan Paul, 1986, forthcoming). I note here my indebtedness to the work of Israel Scheffler, on which much of my thinking about critical thinking has been based. Cf. references to Scheffler's writings cited in the just-mentioned papers.

[8] It seems plausible that teaching in the critical manner might help to develop the critical spirit. But this is an empirical question. Even if it turned out that such teaching did not foster the critical spirit, teaching in the critical manner would still be justified in terms of the general obligation to treat students with the respect due them as persons.

[9] Both "self-sufficiency" and "empowering" are terms suggested by Scheffler. Cf. Scheffler, Reason and Teaching (New York: BobbsMerrill, 1973), Chapter 9, esp. pp. 123-125.

[10] Ibid., p. 143

[11] lbid.

[12] Ibid., pp. 143-144.

[13] Cf. R. S. Peters, "Education as Initiation," in Philosophical Analysis and Education, ed. R. D. Archambault (New York: Humanities Press, 1972), pp. 87-111.

[14] This is very close to McPeck's view, whose debt to Peters is obvious. Cf. John McPeck, Critical Thinking and Education (NY: St. Martin's Press, 1981) pp. 155158. Parenthetical page references to McPeck in what follows are to this book.

[15] Scheffler, Reason and Teaching, p. 79, emphasis in original.

[16] Cf., for example, Jonathan Kozol, "A New Look at the Literary Campaign in Cuba," Harvard Educational Review 48, (1978), pp. 341-377, and references to Bowles and Gintis, Illich, Katz, and Spring therein; Henry A. Giroux, "Theories of Reproduction and Resistance in the New Sociology of Education: A Critical Analysis," Harvard Educational Review 53, (1983), pp. 257-293; Kevin Harris, Education and Knowledge (Boston: Routledge and Kegan Paul, 1979); and the writings of Paulo Freire. The literature here is voluminous.

[17] "Rationality and Ideology," in progress.

[18] Whether or not Wittgenstein's views on forms of life commit him to relativism is controversial. Two well-known works which interpret him in this way are Peter Winch's The Idea of a Social Science (London: Routledge \& Kegan Paul, 1958) and Roger Trigg's Reason and Commitment (Cambridge: Cambridge Univ. Press, 1973). Recent interpretations which do not lead to relativism include, for example, Jonathan Lear, "Leaving the World Alone," Journal of Philosophy 79, 1982, pp. 382-403, and Lawrence Hinman, "Can a Form of Life Be Wrong?," Philosophy 58, 1983, pp. 339-351. The connection between Kuhn and Wittgenstein is not noted as often as it might be. But cf., e.g., Peter Barker, "Uncle Ludwig's Book About Science," Philosophical Topics, Supplement 1982, pp. 
71-78. My earliest discussion of Kuhn and critical thinking is "Kuhn and Critical Thought," Philosophy of Education 1977, pp. 173-179. In that paper I argued that Kuhnian philosophy of science is incompatible with the taking of critical thinking to be a fundamental educational ideal. Jon Fennell and Rudy Liveritte, in their "Kuhn, Education, and the Grounds of Rationality, Educational Theory 29, 1979, pp. 117127 , criticized my view by appealing to an explicitly Wittgensteinian interpretation of Kuhn. Reading Kuhn and Wittgenstein as Fennell and Liveritte do clearly commits one to a relativistic view of the former pair. So 1 argue, at any rate, in my response to the latter pair, "Rationality, Talking Dogs, and Forms of Life," Educational Theory 30, 1980, pp. 135-48. The literature on Kuhn and relativism is voluminous. It is reviewed and assessed in my "Objectivity, Rationality, Incommensurability, and More," British Journal for the Philosophy of Science 31, 1980, pp. 359-375.

[19] Cf. Richard Paul, "Critical Thinking in the 'Strong' Sense: A Focus on Self-Deception, World Views, and a Dialectical Mode of Analysis," Informal Logic Newsletter iv, May 1982, pp. 2-7. It is not clear to what extent Paul is committed to a conception of the role of world views in critical thinking which raises the problem of relativism. This is in part, I think, because he has not addressed himself to the relation between world views and relativism.

[20] I have attempted to do this in several papers. Cf. my "Epistemological Relativism in its Latest Form," Inquiry 23, 1980, pp. 107-117; "Relativism Refuted," Educational Philosophy and Theory 14, 1982, pp. 47-50; "Objectivity, Rationality, Incommen- surability, and More," op. cit.; "Rationality, Talking Dogs, and Forms of Life," op. cit.; "Kuhn and Critical Thought," op. cit.; "Coodmanian Relativism," The Monist 67, 1984, pp. 359-375; "Brown on Epistemology and the New Philosophy of Science," Synthese 56, 1983, pp. 61-89; "Relativism, Truth, and Incoherence," Synthese, 1986 (forthcoming), and "Frameworks, Conceptual Schemes, and Relativism," in progress.

[21] Richard Paul, "An Agenda Item for the Informal Logic/Critical Thinking Movement," Informal Logic Newsletter 5, June 1983, p. 24.

[22] Cf. Part One for references and discussion.

[23] It must be pointed out that many informal logic texts do distinguish between good and bad reasoning (if not good and bad reasons). But it must also be acknowledged that these distinctions are, generally, epistemologically superficial ones, and so do not constitute the sort of account I am calling for here. A similar point is made by Brooke Moore, "Critical Thinking in California," Teaching Philosophy 6, October 1983, p. 324. It should be clear that I do not endorse Moore's claim that "One conception or definition of [critical thinking] is pretty much as 'correct' as the next." (p. 324)

[24] I do not mean to suggest that theorists of critical thinking/informal logic ignore epistemological considerations. The "theory of argument" and "theory of fallacy" as discussed in the literature of ILM are clearly concerned with such considerations. I do think, however, though I shall not argue the point here, that these theorists are not sufficiently cognizant of, or pay too little attention to, the fundamentality of 
epistemological considerations regarding reasons, warrant and justification for the theory of critical thinking. A similar view is expressed by McPeck, op. cit., pp. $72-80$.

[25] McPeck, op. cit., pp. 22-24 and 155-157.

[26] I suspect that the problem McPeck faces here stems in part from his view that the goodness of reasons is "discovered" by "collective human experience" rather than established by epistemological argument. But 1 cannot pursue the point here.

[27] It is worth noting that these difficulties mark McPeck's uncritical acceptance of Toulmin's views on field-dependence. McPeck cites Toulmin (pp. 32-33; 79-80) to the effect that criteria of argument assessment are intra-, not interfield; but fails to consider the obvious self-reflexive question regarding the generality or fieldspecificity of the criteria by which Toulmin's claim is itself to be evaluated. I believe that McPeck is far too uncritical of Toulmin's views on logic, rationality, and epistemology. For critical discussion of Toulmin's most recent foray into the area of critical thinking/informal logic, cf. Ralph Johnson's thorough review, "Toulmin's Bold Experiment," Informal Logic Newsletter 3, \#2, March 1981, pp. 16-27 and 3, \#3, June 1981, pp. 13-19; for consideration of Toulmin's views on rationality and epistemology, cf. my "Truth, Problem Solving and the Rationality of Science," Studies in History and Philosophy of Science 14, 1983, pp. 89-112.

[28] The sort of generality I am here arguing is necessary for a satisfactory epistemology of critical thinking is analogous to Walton's and Woods' demands for generality in the theory of fallacy. Cf.
Johnson and Blair, "Introduction," in J. Anthony Blair and Ralph Johnson, eds., Informal Logic: The First International Symposium (Inverness, California: Edge Press), 1980, regarding Walton's and Woods' papers.

[29] Cf. W. Spohn, "Deterministic and Probabilistic Reasons and Causes," Erkenntnis 19, 1983, pp. 371 396.

[30] Cf. Part One.

[31] A related point is made by Scriven, "The Philosophical and Pragmatic Significance of Informal Logic," in Informal Logic, op. cit., p. 157.

[32] Johnson and Blair's brief note on the ILM's emerging agenda "'From the Editors," Informal Logic Newsletter, vol. 5, December 1982, pp. 1-2) is notable for its failure to mention the philosophical issues I have discussed. To my knowledge the only move in this direction by a member of ILM besides MCPeck is Richard Paul's call for attention to philosophy of education. Cf. footnote 21 above.

[33] The phrase is Robert Binkley's. Cf. Binkley, "Can the Ability to Reason Well Be Taught?" Informal Logic, op. cit, , p. 87.

[34] I take this call to be at least somewhat parallel to Paul's call for critical thinking in the "strong" sense. I regret that space forbids detailed consideration of Paul's views.

[35] Though not "conceptually necessary" in the way McPeck suggests.

Dr. Harvey Siegel, Department of Philosophy, University of Miami, P.O. Box 248054, Coral Gables, FL 33124 